$\mathrm{Oz}$

Volume 8

Article 14

$1-1-1986$

\title{
Architecture as Place Making: a Sustainable Farmstead and Staff Housing
}

Steven Downen

Stanley Koehn

Douglas Pierce

See next page for additional authors

Follow this and additional works at: https://newprairiepress.org/oz

(c) (i) $(9)$

This work is licensed under a Creative Commons Attribution-Noncommercial-No Derivative Works 4.0 License.

\section{Recommended Citation}

Downen, Steven; Koehn, Stanley; Pierce, Douglas; and Rantis, Daryl (1986) "Architecture as Place Making: a Sustainable Farmstead and Staff Housing," Oz: Vol. 8. https://doi.org/10.4148/2378-5853.1122

This Article is brought to you for free and open access by New Prairie Press. It has been accepted for inclusion in Oz by an authorized administrator of New Prairie Press. For more information, please contact cads@k-state.edu. 
Architecture as Place Making: a Sustainable Farmstead and Staff Housing

Authors

Steven Downen, Stanley Koehn, Douglas Pierce, and Daryl Rantis 


\title{
Architecture as Place Making :
}

\author{
A Sustainable Farmstead and Staff Housing
}

\author{
Steven Downen \\ Stanley Koehn \\ Douglas Pierce \\ Daryl Rantis
}

\author{
Critics: Dale Bryant \\ Gary Coates \\ Gene Ernst \\ Lew Seibold
}

\section{Introduction}

A growing number of architects are becoming aware of the necessity to design with respect and response to the natural ecosystem. The advent of environmental criteria in architecture is part of a burgeoning realization that industrial societies are not environmentally sustainable. Architectural design has not only turned its back to the natural environment, but has also become insensitive to the psychological nurturing needs of people.

In a response to this dilemma, the Meadowcreek Project in Fox, Arkansas has initiated a unique program with the hope of defining some possible solutions. The Project is a nonprofit center for education and research in applied ecology, agriculture, renewable energy systems, forestry, wildlife, as well as ethical, social, economic, and political aspects of sustainability. Gary Coates and David Seamon, professors of Architecture at Kansas State University conducted an introductory studio in the spring of 1984 that dealt with the problem of designing activities and longterm planning for Meadowcreek. As a basis a pattern language approach, developed by Christopher Alexander, was employed. It allowed for piecemeal growth that would produce a whole greater than the sum of its parts and permitted ongoing participatory design as part of the curriculum. Because of the success of this project, the Meadowcreek staff decided to propose two design

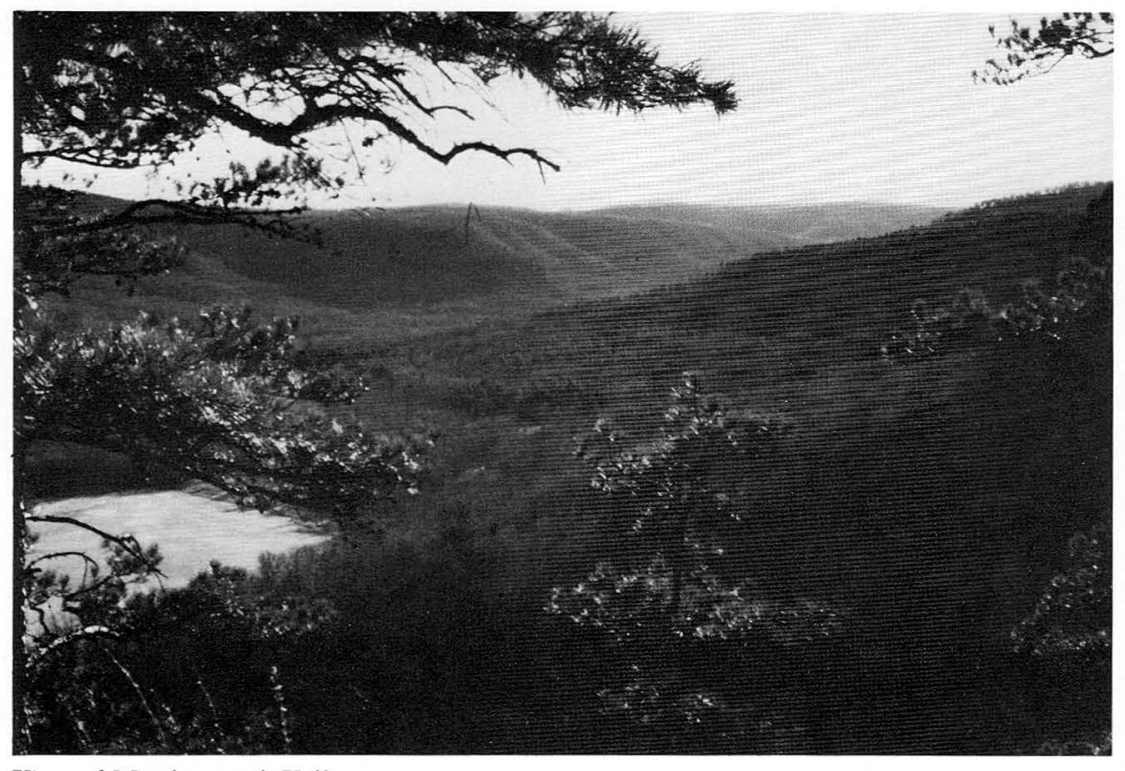

View of Meadowcreek Valley.

problems to be used as thesis projects for fifth year students at KSU. The problems were to design a model sustainable farmcenter and staff housing. Upon completion of the designs and graduation, the students would spend the following summer and fall involved in the actual construction of the buildings, fulfilling the concept of participatory education. Four students under the guidance of Gary Coates, formed two-man design teams with Daryl Rantis and Stanley Koehn designing the sustainable farm, and Steven Downen and Douglas Pierce designing the staff housing.

Since each of us had participated in the spring studio, an understanding of the ideals and future planning for Meadowcreek was already perceived.
Programming for the two projects began in late summer, 1984. Immediately we found ourselves stumbling over issues, goals, and objectives such as what is What is a sustainable farm? What is the connection between agriculture and architecture? How can we design with sensitivity to the natural environment of the Arkansas Ozarks and with the vernacular building styles? How can we use the natural heating and cooling potentials of the region? Finally how do we incorporate Meadowcreek's philosophy with our emerging architectural philosophy?

Many hours were spent researching past and present methods of sustainability. We had discussions with the managers of the future farmcenter and visited design that results in "sustainability?" organic farms. Definition was given to issues and goals from a variety of sources, some outside the realms of architecture.

We employed the pattern language approach in programming this design problem since it proved successful in the initial master planning project with Meadowcreek. Patterns were chosen from Alexander's A Pattern Language which we felt fit the design problem and then fashioned some of our own that we regarded as necessary to complete the requirements of both projects.

In January, 1985 the four of us traveled to Meadowcreek and participated in the winter session that focused on "sustainable agriculture." We also performed preliminary site work on both projects including topographic surveys. Documenting as much information as possible was necessary to understand the ecosystem we would be invading. An intimate knowledge of the site was needed so that an environmentally sensitive design could be created. During the same period we also studied the vernacular architecture and regional construction techniques. After the session ended we returned to KSU and continued the design process.

The Farmcenter

The farmcenter consists of a farmhouse, outbuildings, orchards, gardens and pasture. Because of limited construction resources, only the farmhouse could be 


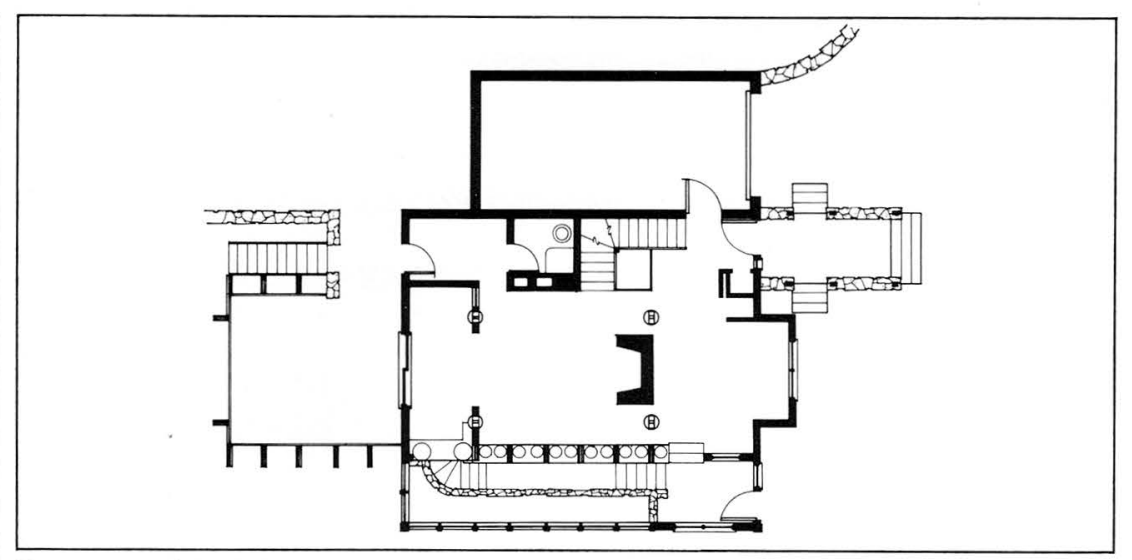

Farmcenter plan.

constructed. The rest of the farmcenter would be completed at a later date. The resident clients were a young couple and their daughter. Although the farmcenter was designed to fit the needs of this family, it is flexible enough to fit the needs of any future occupants.

The farmhouse required a kitchen, living room, master bedroom, two bedrooms, child's realm, bathrooms, root cellars, meeting room, office, food producing greenhouse, and storage for a fire truck.

In the early design stages the clients had familiarized themselves with A Pattern Language. This gave us and the clients a common basis for discussion and helped define their lifestyle. Although participatory design was attempted through the pattern language approach, it was not entirely successful because of the geographic distance between Fox, Arkansas and Manhattan, Kansas. Consultations were difficult to arrange by long distance.

The architectural concepts for the farmhouse are based on a theory of place and the idea that the building should complete the place instead of detract or overpower it. The vertical form of the house rises from a stone base with converging stone walls which merge into a wood frame building, capped by a large sheltering roof in a response to the trees which shade the site. The form of the building respects the vernacular dog-trot house, which is utilitarian in needs and simple in nature.
The dog-trot pattern was widely used by early settlers in the Ozarks to facilitate passive cooling. It has two main rooms separated by a covered breezeway. Many family activities during the warm months took place outdoors where the breezeway allowed more comfort by channeling breezes which cooled the air.

In the abstraction of this concept the breezeway is delineated as an out door space but is actually indoors. This space can also be considered as a scaled-down great room or living space in which most functions of the house hold could take place at one time or another. On the south side of the great room is an integral three story greenhouse with large window panels that offer a beautiful view of the Boston Mountains to the south. A spacious glass doors which open to a second story deck. In winter the great space is a solar collector and in summer functions as the dog trot did by venting air through the two-story space and out the roof. The other spaces in the house become support units with a more in door quality as opposed to the greenery and use of materials that help delineate the great room as an outdoor space.

The building is an expression of its parts, marrying post and beam with balloon frame construction and a system of ornamentation celebrating only those things that are necessary to the function of the household The house also responds to the enview to the west is obtained by sliding

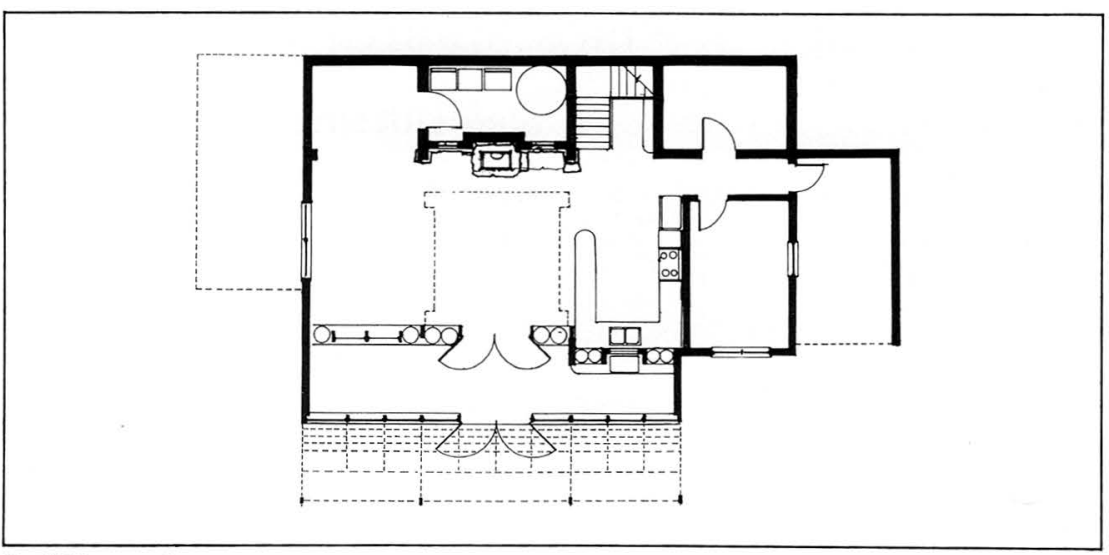

\section{Staff House plan.}

vironment through the use of solar gain heating, on site firewood, earth berming, gravity forced water system, composting toilets, grey water usage, adequate ventilation systems, root cellars, future photo-voltaic use, a builtin greenhouse, and available land space for orchards, gardens, animal husbandry and crop farming

\section{Staff Housing}

Two staff housing units were to be designed, of which one would be selected for construction. It is a house for future employees and should serve as a single-family dwelling or as a house for two individual staff members or interns. The duration of stay for the occupants could vary from six months to several years. To accommodate these changing occupancy requirements, this house must be flexible and diverse enough to give privacy to the various individuals involved or unity to a family. This aim is achieved by providing spaces that fulfill the patterns of: (1) degrees of publicness; (2) intimacy gradient; (3) common areas; (4) couple's realm; and (5) children's realm. By actualizing these patterns through architectural design, we hoped to create a working solution. Not having actual clients for this project gave us a certain freedom not possible for the farmhouse. There were no specific clients' needs or requests to conflict with the solutions that we thought would fulfill the requirements of the program and patterns. Instead of clients, co-director of Meadowcreek, Wilson Orr had final say on what we could or could not do. Wilson insisted on a minimal budget which proved to be a very realistic experience in an architect/client relationship. Because of this requirement, we soon realized that a bare-bones house would lack comfort unless we could provide a simple design solution that functioned both spatially and thermally. We relied on A Pattern Language to enhance the quality of the modest design.

The language we used helped to find the solution to our spatial problem. By designing one pattern at a time as outlined by Christopher Alexander in The Timeless Way of Building, we worked from the larger patterns toward the smaller. Working in this way allowed each additional pattern to redefine, "repair" and "enhance" the previous ones until all chosen patterns were complete and integrated with each other. When this interaction among patterns is in harmony they will maintain the "interconnectedness" needed to create the "quality without a name" as defined by Alexander. These so-called "live patterns" helped us create this quality so the dwelling can "become part of nature," in harmony with its occupants and the natural systems in which they exist. This language gives the Meadowcreek Project the ability to establish a type of "genetic code" to govern the Project's future design and construction. 


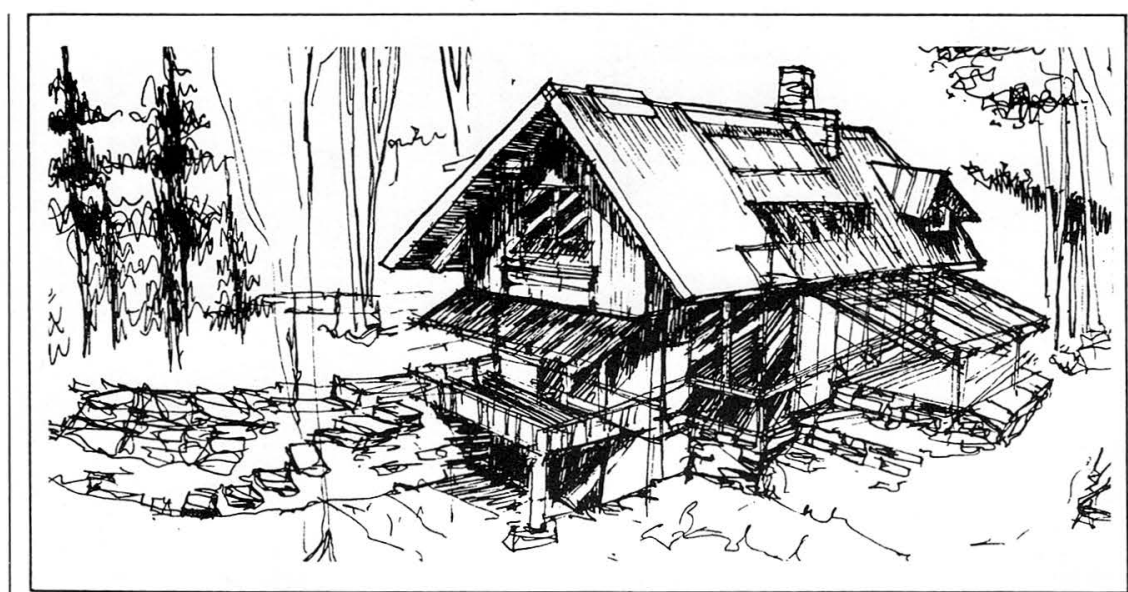

Farmcenter preliminary perspective

Today's society lacks an underlying "basic language" that reflects the bioregionality of the area. This creates buildings and towns that evolve from "dead patterns." Our goal is to discover the patterns that could liberate life, then establish them as a means by which the Meadowcreek Project could create their environment. By giving us the chance to build our designs Meadowcreek provided us with the opportunity to test our chosen patterns and to actually experience the spatial geometries defined by them.

\section{Construction Phase}

Probably the most innovative phase of our Meadowcreek experience was the construction stage, in which we supervised the building crew and participated in the construction. We found that the design process did not stop after the drawings were done. Once construction got underway, new and better details were continually developed. Daily we became more familiar with on site decisions. We encouraged all parties involved to participate in the design process. As unforseen problems arose we consulted with the construction crew, Project managers, clients, and ourselves to find a solution. This resulted in a variety of options from which to choose and learn. We often found ourselves suddenly sketching ideas on a piece of scrap lumber or on the side of a wall stud. We affectionately
As construction progressed we were able to see our designs come to life. Spaces and details that appeared to work out on paper were simplified to ease construction, or adjusted for aesthetics. For instance, on the farmhouse we mocked up four different window mullion details for the exterior of the greenhouse. From these models, we were able to choose the best solution, which involved a mullion pattern more delicate than what had originally been designed. began to evaluate the strengths and weaknesses of the designs. It seems our most important lessons were gained through our mistakes. For instance we learned an important lesson in working with concrete. In pouring a section of the farmhouse foundation wall, a portion of the structure honeycombed. The result was that we had to chip out the faulty portion, reform, and patch it. We became familiar with the many properties of concrete. While we learned calculation and formulas in the classroom, in the field we learned just how heavy a shovel full was, how the concrete mixture separates when poured into awkward framework, or how it irritates the skin and burns the eyes.

The rhythms of the construction phases and crew morale made the entire building experience a continuous celebration which involved both pain and a daily sense of achievement. This celebration and place-making was an
Once the two projects were built, we

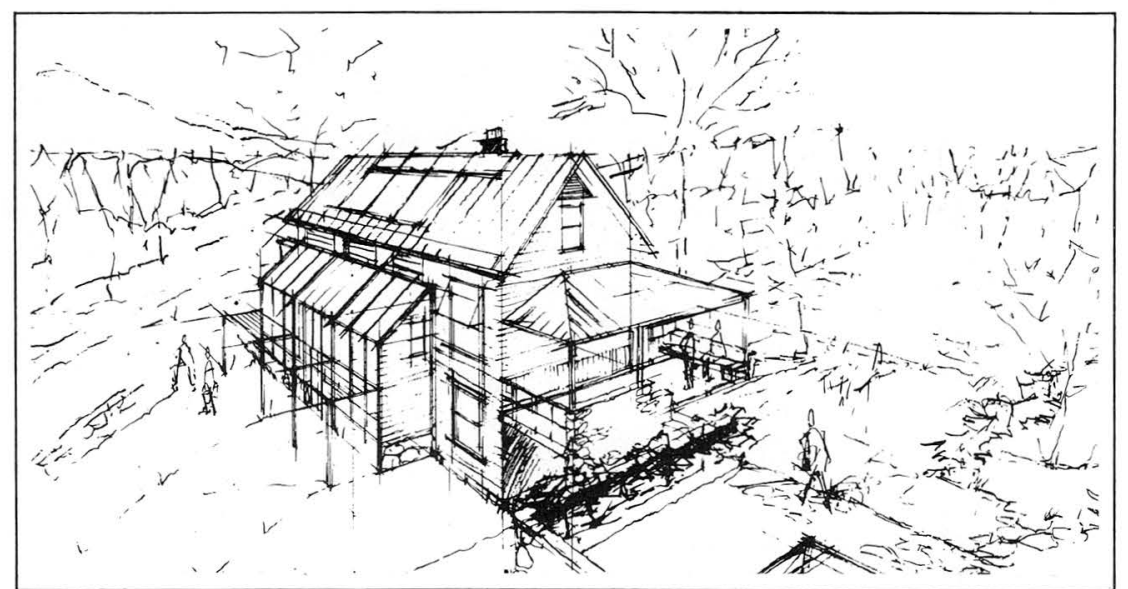

Staff House preliminary perspective.

educational process that strengthened both our understanding of the built environment and the world around us.

\section{Conclusion}

Today's prevailing architectural styles are based, and dependent on high capital investment and the availability of infinite amounts of cheap energy. A wreckless freedom and decadence of design has occurred, resulting in architecture that does not nurture the human spirit or integrate people with the natural environment. Artificial environments have been created that deny people a healthy physical and psychological habitat.

Mankind stands at the edge of a cultural transformation. It is clear that we are witnessing the end of the fossil fuel liquid energy era and are entering an age of alternate renewable energy systems.

Along with energy changes, human needs and values will be affected. Historically architecture has responded to changing needs, values, and technologies. On occasion fundamental paradigm shifts occur that go well below the surface quality of trends or style. After understanding this dependence on imported fuels plus continually measuring the effects of pollution and waste from a consumer society, more people are revising their values. With values changing so do places to dwell. With new values and the use of new and appropriate technologies architecture is on the verge of a major shift that is not controlled by fad or fashion, but is responding to the awareness of natural limits and demands for a high quality of life.

The present-day approach to education and the public education system will undoubtedly change in response to the same needs. Meadowcreek offers handson education where the student not only learns from typical classroom activities, but also by practical experiences. This type of education produces many valuable results.

How can a designer of the environment understand this art/science without realizing the connection between designing and building? As a result of the present approach to design education many environmental designers graduate from college only understanding what they learn from books. In an effort to resolve this fundamental error in the education system Meadowcreek allowed us to extend our education beyond the typical graduation point, by erecting the designs and obtaining experience in construction management. With a better understanding of the construction process we will become better designers and perhaps contribute to an emerging architecture that is not only right for the time but also right for the needs of people and the environment. working with the construction crew in 

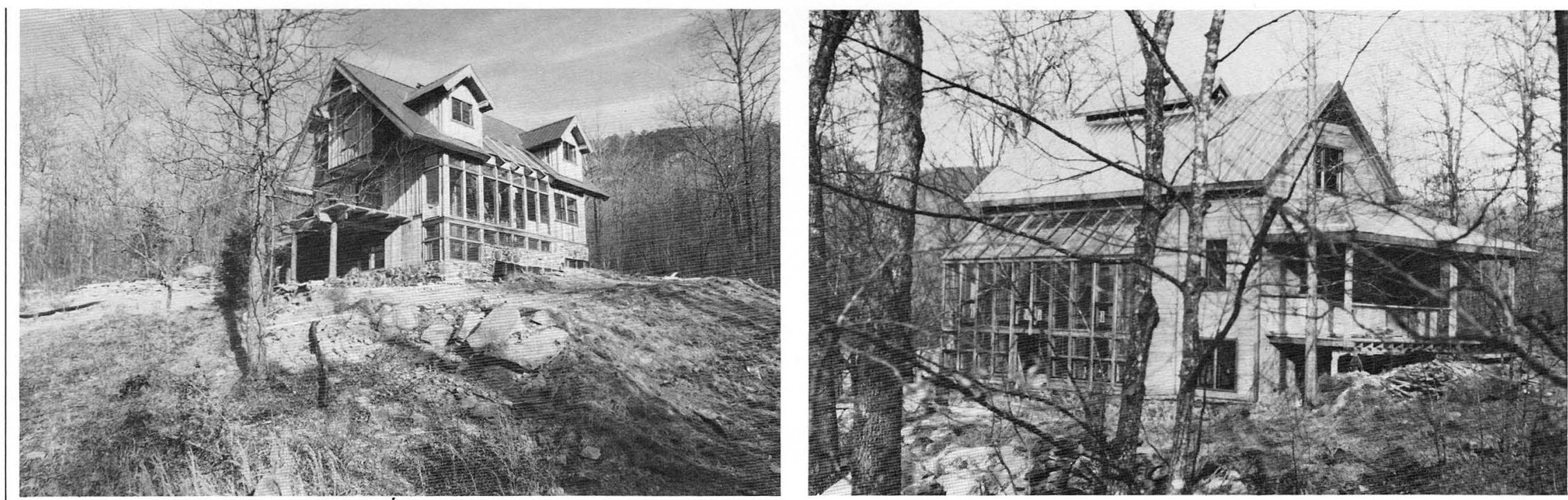

\section{Farmcenter.}

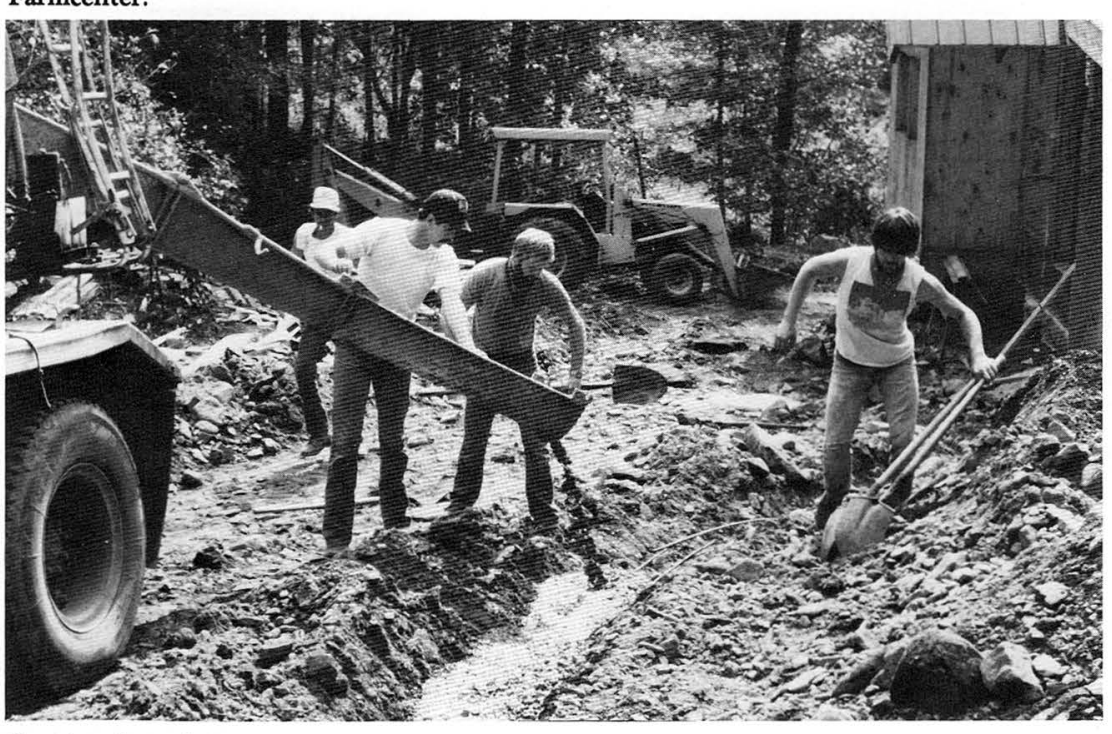

Staff House.
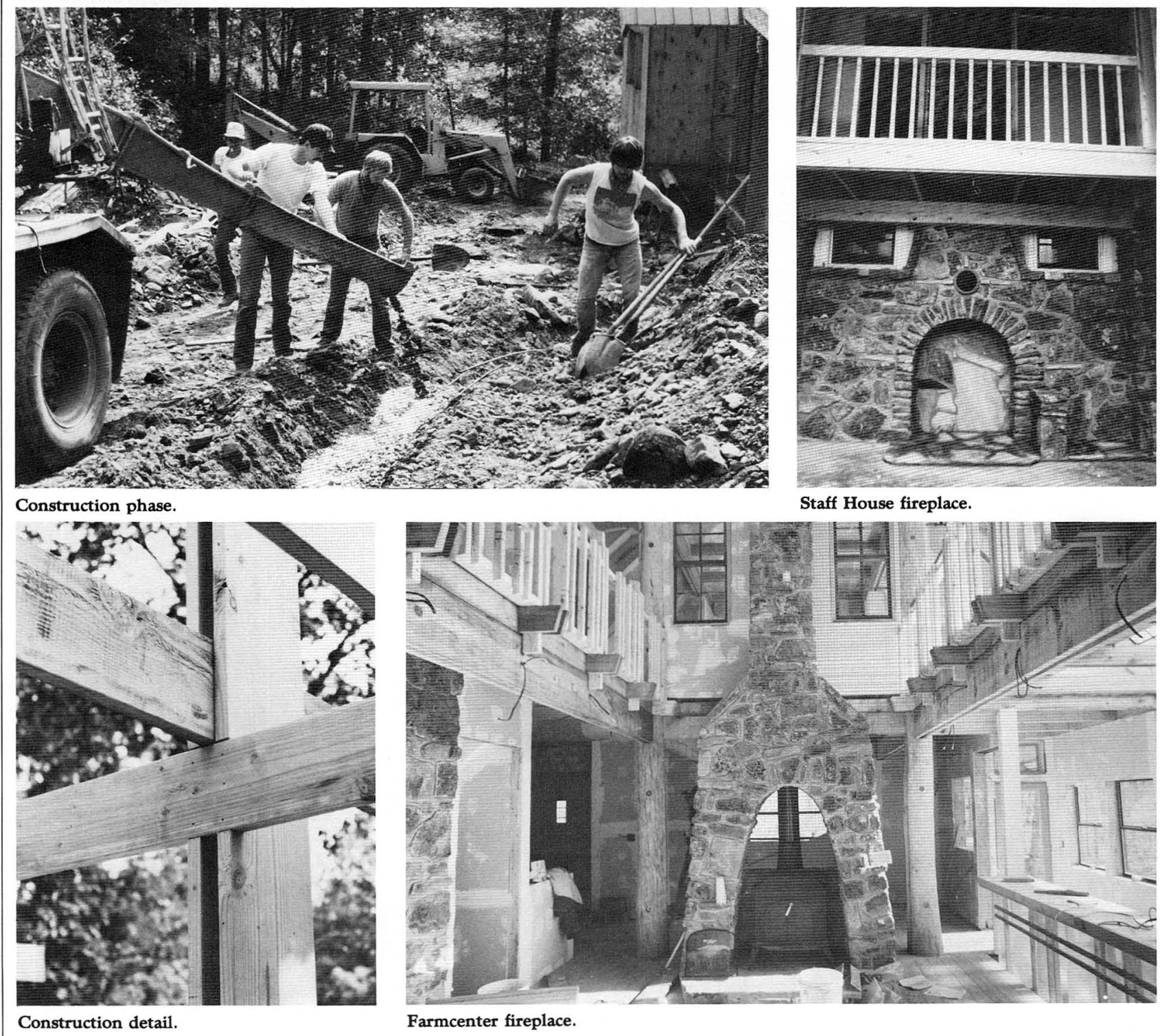

Staff House fireplace.
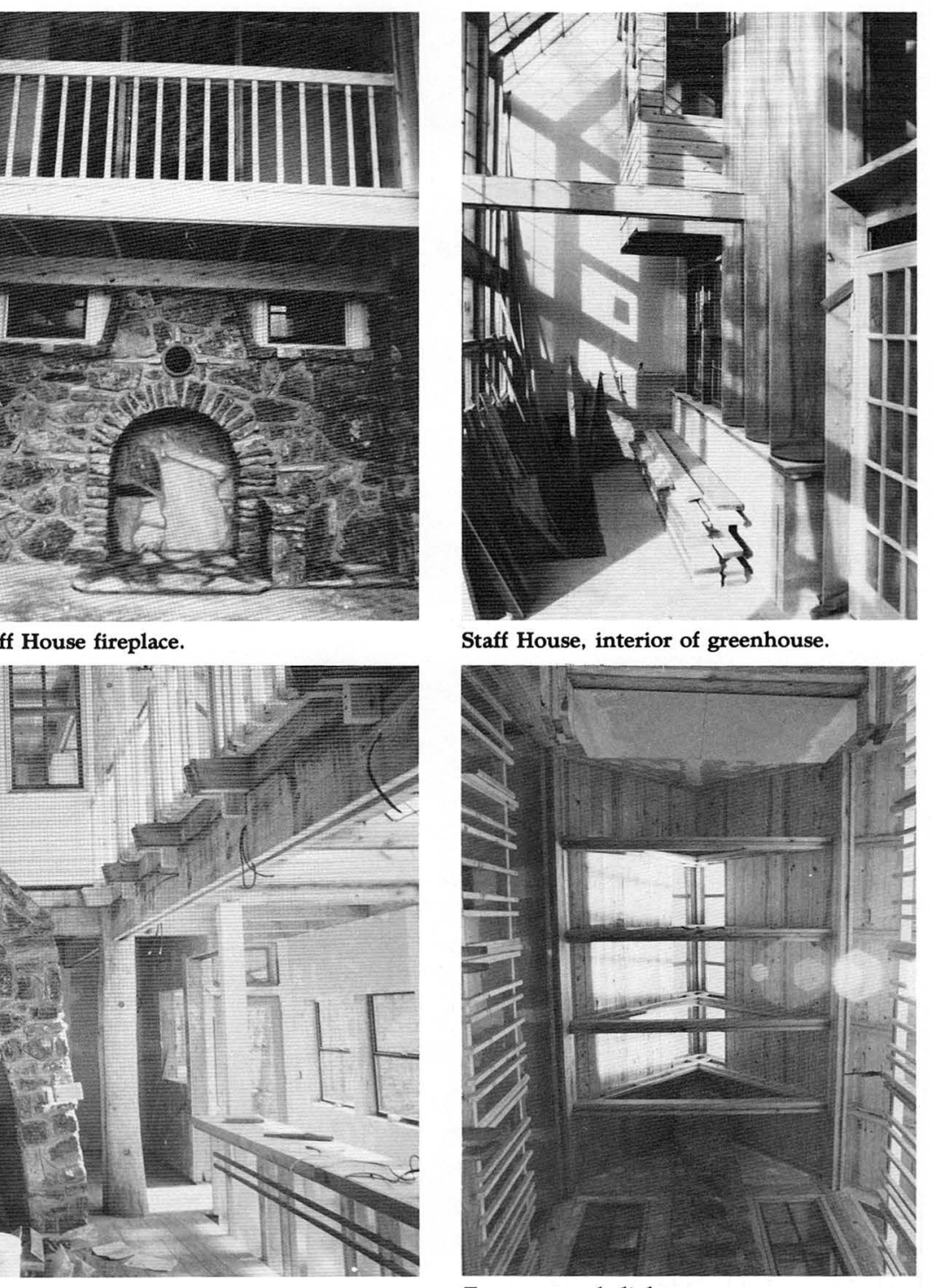

Staff House, interior of greenhouse.

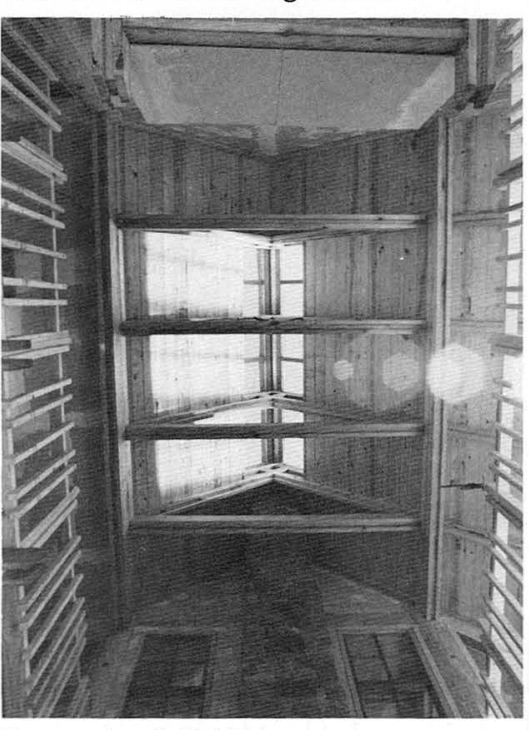

Farmcenter fireplace.

Farmcenter skylights. 